\title{
Seasonal Variations of the Surface Nutrients and Hydrography in the Norwegian Sea
}

\author{
Ahmed Ibrahim, Are Olsen, Siv Lauvset, and Francisco Rey
}

\begin{abstract}
Seasonal variations of surface nutrients and hydrography data obtained in period $(1997-2010)$ by the Institute of Marine Research over three transects: Fugløya-Bjørnøya, Gimsøy and Svinøy located in the Norwegian Sea have been studied. The results over the Fugløya-Bjørnøya transect show good signature of the seasonal cycle of nitrate $(10.4 \mu \mathrm{mol} / \mathrm{Kg}$ in winter time, $0.8 \mu \mathrm{mol} / \mathrm{Kg}$ in bloom time, and 0.6 in post-bloom time), and temperature (4.8 ${ }^{\circ} \mathrm{C}$ in winter time, $6.5^{\circ} \mathrm{C}$ in bloom time, $9.5^{\circ} \mathrm{C}$ in post-bloom time), reflecting both bloom and post-bloom periods. The Gimsøy transect shows a weak seasonal cycle of nitrate and temperature in the outer part because there is no enough data during the bloom and post-bloom period. But the middle and inner part show good seasonal cycle of nitrate and temperature during the two periods. Finally, the Svinøy transect shows good seasonal cycle of nitrate $(10.1 \mu \mathrm{mol} / \mathrm{Kg}$ in winter time, 2.0 $\mu \mathrm{mol} / \mathrm{Kg}$ in the bloom time, $0.9 \mu \mathrm{mol} / \mathrm{Kg}$ in post-bloom time), and temperature $\left(7.1^{\circ} \mathrm{C}\right.$ in winter time, $7.8^{\circ} \mathrm{C}$ in bloom time, $12.4^{\circ} \mathrm{C}$ in post-bloom time), during the bloom and post-bloom.
\end{abstract}

Index Terms-Norwegian Sea, seasonal variations, temperature, nutrients, spring bloom, post-bloom, salinity.

\section{INTRODUCTION}

Marine primary production and its seasonal variations has been the subject to extensive studies. This is because it is the foundation of the food chain of the ocean, and plays an important role in the carbon dioxide cycle, thus the climate change. Phytoplankton is the main manufacturer of pelagic marine waters, an essential part of the marine food web, thus the entire ecosystem, affecting fishery resources, nutrients cycling, trophic dynamics, and habitat conditions [1]. Additionally, plankton show strong response to environmental variations, making them good indicators of environmental disturbance [2]. The important ecosystems around the world are the coastal upwelling regions, and the high latitude regions where the spring bloom is found [3]. The Nordic Seas are one of these important ecosystems [3]. The main work of my thesis concerns the Norwegian Sea, and specifically the seasonal spring bloom variations in the Norwegian Atlantic Current (NAC) and Norwegian coastal current (NCC) along the Norwegian coast. This done by

Manuscript received January 19, 2014; revised March 13, 2014. This work was support in financial, academic and technical by the NOMA program, specially the coordinator of the program, Dr. Knut Barthel; data by Institute of Marine Research, Bergen-Norway.

Ahmed Ibrahim is with the Geophysical Institute, University of Bergen, Norway (e-mail: a.saif42@yahoo.com).

Are Olsen and Siv Lauvset are with Bjerknes Centre for Climate Research, University of Bergen, Norway (e-mail: are.olsen@gfi.uib.no, siv.lauvset@bjerknes.uib.no).

Francisco Rey is with Institute of Marine Research, Norway (e-mail: pancho@imr.no). evaluating hydrographic and nutrients, using data obtained at three transects perpendicular to the Norwegian coast.

\section{Physical Setting}

The global ocean circulation is dominated by the thermohaline circulation (see Fig. 1), also known as the Great Conveyor Belt [4]. It is considered as large scale processing around the world. The Nordic Seas is one of the few places where deep water is formed, is considered as key area for thermohaline circulation [5]. The warm Atlantic current moves northward to high latitude, losing heat to atmosphere and become dense enough to sink down as deep cold water. In the Indian Ocean the cold water comes up through upwelling to make balance with other cold water comes down. This also happens in the Pacific Ocean. As the result these entire processing make the oceans ventilated and bring up high nutrients for the biological processes [6].

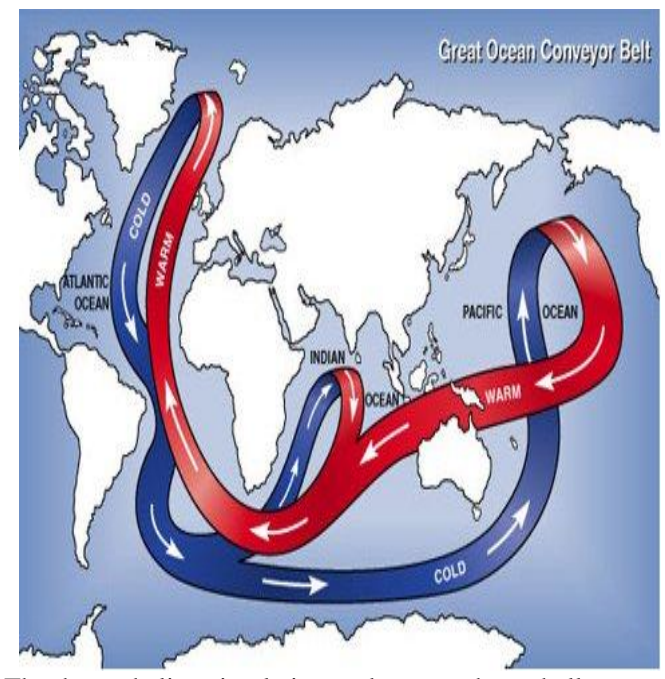

Fig. 1. The thermohaline circulation, red arrows show shallower and warm water; blue arrows show deep and cold water [7].

\section{A. Bathymetry of the Nordic Seas}

The bathymetry of the Nordic Seas is shown in Fig. 2. Nordic Seas consist of three seas named according to lands boarding the region, which are Norway, Iceland, and Greenland [8]. It connects with Arctic Ocean to the north, through the Fram Strait with a sill depth of $2600 \mathrm{~m}$. To the south, the Greenland Scotland Ridge connects it to North Atlantic Ocean [8]. The Nordic Seas contain four basins two of them are to the north and west of the mid-ocean ridge; they are named Boreas basin with depth of $3200 \mathrm{~m}$ and Greenland basin with depth 3400 to $3600 \mathrm{~m}$ in the Greenland Sea [8]. The two other basins are found to the south in the Norwegian Sea they are named Norwegian basin with a depth of more 
than $2200 \mathrm{~m}$ deep $\mathrm{m}$ and Lofoten basin, about $3200 \mathrm{~m}$ deep [8].

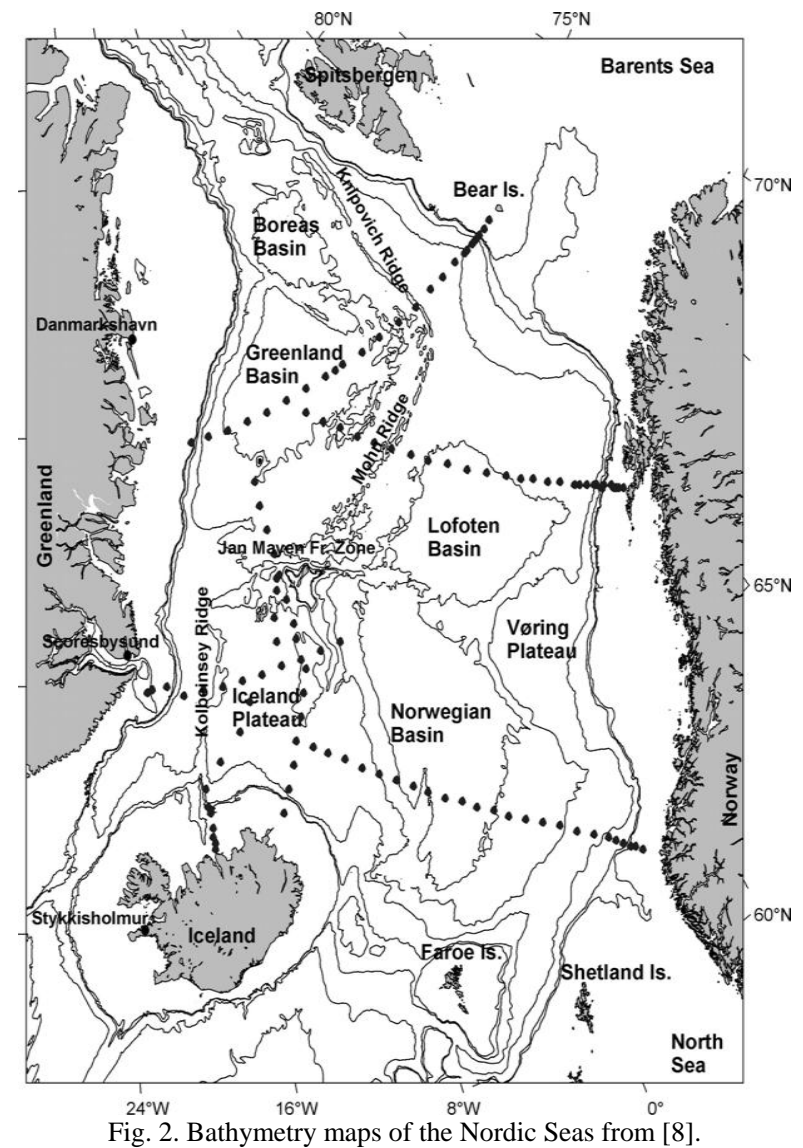

The Mohn ridge separates the Lofoten basin from the Greenland basin. In addition there are two plateaus, one of them is located off Greenland, to the east, and it is called the Iceland plateau, the other is called the Vøring Plateau, located eastward from the Norway, and bordered by the Lofoten basin to the north and Norwegian basin to the south [8].

\section{B. Water Masses and Circulation of the Nordic Seas}

In the Nordic Seas there are four main surface water masses: (i) the Atlantic water (AW) to the east which flows northwards to the Arctic Ocean, (ii) the Polar Water to the west that flows southwards from the Arctic Ocean, the mixing product between these constitutes the (iii) water mass Arctic Water (ArW), and all the way to the east, along the Norwegian Continental shelf we find (iv) Coastal Water, flowing northwards in the Norwegian Coastal Current (NCC) [8]. In the Nordic Seas from the south to the north we have warm water known as Atlantic water with high salinity around 35 and 35.26 and temperature between $3{ }^{\circ} \mathrm{C}$ and $4{ }^{\circ} \mathrm{C}$ [8]. On the other hand from south to the east of Greenland we have cold water known as polar water to the west coming from Arctic Water with salinity low than 34.2 [8]. Moreover and between these, and result of mixing the Norwegian Sea Arctic Intermediate water is formed and flow from the south to the north with salinity below 34.89 [8]. The current circulation track from the Atlantic Ocean northward to the Nordic Seas was dominated by the weather change [8]. There are three location of North Atlantic Ocean inflow to the Nordic Seas [8]. The flow over the eastern Denmark Strait is known as North Icelandic Irminger Current. The second flow across the Iceland-Faroe Ridge is known as the Faroe Current [8]. The last flow is over the Faroe Shetland Channel Know as Atlantic Inflow [8]. On the other hand most of waters continue into Norwegian Basin which oncoming the Vøring Plateau, its transition northwest toward Jan Mayen [8]. Atlantic Water from the West Spitsbergen induces current deflect into the northern Greenland Basin and Boreas Basin [8]. Moreover the water masses in the Nordic seas were resulted due to their contacting with many different waters.

\section{BIOLOGICAL FEATURES}

Phytoplankton is the first type of organisms, a single cell in the marine food web. Through photosynthesis these organisms combine nutrients (nitrate, phosphate), and carbon dioxide into organic compounds. Primary production sustains the global marine ecosystem and its harvest-ability [9]. Primary production is also important for the oceans ability to store carbon dioxide. The exchange of carbon dioxide between the atmosphere and ocean depends on the concentration of $\mathrm{CO}_{2}$ on the ocean surface [10]. Phytoplankton consumes carbon dioxide which reduces the concentration of $\mathrm{CO}_{2}$ in the surface waters, driving a flux of $\mathrm{CO}_{2}$ from the atmosphere and into the ocean to make equilibrium between the air and water [10]. The most important global patterns of marine primary production follow similar patterns as the quantity and distribution of light and nutrients [3]. There are three main types of regions, the tropical regions, the subtropical regions, and the sub-polar regions [3]. The oligotrophic tropical regions are where the exchange of nutrient is limited by pycnocline, which implies low rate of production in the surface layer due to low nutrients [3]. The other source of nitrate is nitrogen regenerated by the grazers [3]. The feature of oligotrophic is that appears little seasonal variability, and high stability of water column [3]. On the other hand trade wind at equator is carrying to west and increase the flow in the mixed layer alongside this direction [11]. In this area the Coriolis force has important role that can cause deflection of westward currents to the north whereas the westward currents in south turned to south [3]. These processes are known as equatorial upwelling. The water from the deep ocean is nutrients rich and phytoplankton poor [3]. The subtropical region appears between the sub-polar and tropical regions and according to Longhurst et al. (1995) [12], there are many subtropical areas, covering approximately half the area of the world ocean [3]. Moreover there is a short period in winter when deep mixing refills the upper layer with nutrients. The phytoplankton in the subtropical system is never light limited, is nutrients limited most of year [3]. The sub-polar region lies between $50^{\circ} \mathrm{N}$ and $70^{\circ} \mathrm{N}$. When we move to northwards, the downward mixing by convection cooled water at the surface of the ocean addition to wind-driven turbulence to make deeper mixed layer in the winter season [3]. The turbulence induces nutrients to the euphotic zone [3]. Also the phytoplankton cells are sinking deeper and deeper and spend long time under the euphotic zone, while the photosynthesis is surpassed by the respiration [3]. Ultimately in the spring the mixed layer becomes shallower and the 
phytoplankton cells is trapped over the pycnocline and spend more time in the euphotic zone thus great blew up of phytoplankton that known as spring bloom [3].

\section{A. The Norwegian Sea Ecosystem}

The Norwegian Sea is one of the richest and highly productive ecosystems of the world oceans (see Fig. 3). This high productivity is due to the spring bloom which occurs through phytoplankton trapped in the shallower mixed layer rich with nutrients obtained from the deep ocean where the nutrients accumulated in the winter. In the Nordic Seas the hydrographic features of the natural borders (Arctic and Coastal fronts in the Norwegian Sea and the Polar Front in the Barents Sea) are important matter when we going in the ecosystem composition [13]. Also the topography effects on the ecosystem composition [14]. The Norwegian Sea has a short food chain that contains phytoplankton, zooplankton, and fish [14].

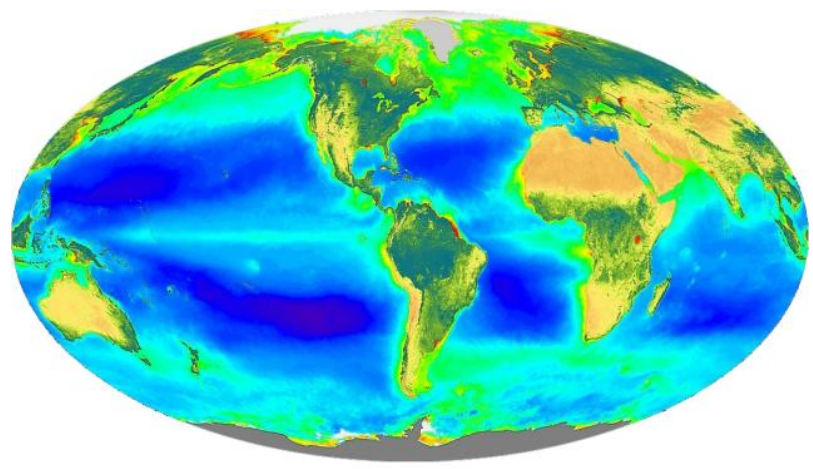

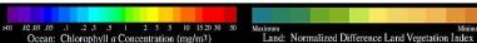

Fig. 3. The global primary production includes the Norwegian Sea productivity [15].

The most important phytoplankton types that exist in the Norwegian Sea are diatoms, dinoflagellates and coccolithphorids [16]. Diatoms are starting the production in early March through April [16]. Diatoms control the spring bloom at the beginning of bloom. Later the flagellates like phaeocystispouchetii that controlled the phytoplankton [16]. The most important zooplankton group in the Norwegian Sea ecosystem is called copepod [17]. The main copepod is the Calanus finmarchicus and does grazing on the spring bloom [18]. The third element of the Norwegian food chain is represented by Atlantic herring, capelin, Atlantic cod saithe and blue whiting [16].

\section{B. Primary Production in the Nordic Seas}

Oceans and seas on the earth contain in their interior, many of the biological systems and biodiversity, which are part of the overall system on the earth, where they have active roles in the changes of climate. There are several factors that control the process of primary productivity in the oceans, which varies with the geographic location [19]. In the Nordic Seas the factors that dominate the primary productivity are light, temperature, and nutrients supply [20]. In addition grazing is considered one of the factors that effect on primary productivity [20]. Sea ice melting also affects primary productivity in the Nordic Seas [20]. Ryther (1956) [21] observed that the light becomes a limiting factor for phytoplankton development in winter, thus low biomass of chlorophyll-a. The depth of the mixed layer is at its maximum in February, deeper than $100 \mathrm{~m}$, till the end of April (3). Johannessen and Gade (1984) [22] assumed that the phytoplankton population was conserved low result to deep vertical mixing. There is no indication of thermal stratification in April [3]. The wind induces the vertical mixing [23]. The grazing may have a clear impact on the spring bloom in areas with delayed thermal stratification [24].

\section{DATA AND METHODS}

\section{A. Hydrographic Data}

The hydrographic data that were used in this thesis are temperature, salinity, and nitrate $\left(\mathrm{NO}_{3}^{-1}\right)$. In this thesis data from the years 1997-2010 were used. The data were obtained by the Norwegian Institute of Marine Research (IMR) on three of their repeat hydrography transects: The Fugløya-Bjørnøya transect in the Barents Sea, the Gimsøy transect in the Lofoten Basin, and the Svinøy transect in the Norwegian Basin. The three transects are shown on the map and perpendicular along the Norway coast (see Fig. 4). Water samples were collected throughout the water column and then put in the polyethylene vials chloroform to prevent samples from change [25]. The instrument used to analyze the water samples is called Auto analyzer, and was set up to standard methods. And it is designed to determination the nutrient salts in sea water [26]. The basic concept of the nitrate, and phosphate analysis includes reduction of the nutrient targeted Cd-column and addition of known amount from reagents have ability to produce complex compound with color that can be detected by spectrophotometer instrument at known wavelength [27]. The amount of produced colored compounds is proportional to the nutrient salt analyte existing in the solution [28]. As shown in (Fig. 4) each of the three transects cover the main paths of the Atlantic water (AW) shown with bold red line beside the Norwegian Coastal Current with bold yellow line and their front with dashed orange line. Also the Atlantic water and Arctic water with dashed violet line representing the Arctic front from the other side to the west. More further its shows the front of Arctic Water comes out to the west and in other time comes in to the east. At each transect the average values in the upper ten meters for an outer, middle and inner part were determined. The limits between these were based on general knowledge of the hydrography aiming to capture regions dominated by Coastal and Atlantic waters for the inner and middle parts, respectively, (see Fig. 5). In the outer parts there may be additional influence of Arctic surface waters in at the Svinøy and Gimsøy transects, and of Polar Water at the Fugløya-Bjørnøya transect. From (Table I), at the Fugløya-Bjørnøya transect the outer part is north of $73^{\circ} \mathrm{N}$, the middle part between $72.0^{\circ} \mathrm{N}$ and $73^{\circ} \mathrm{N}$, and the inner part between $70.50^{\circ} \mathrm{N}$ and $72.0^{\circ} \mathrm{N}$. On the Gims $\varnothing y$ transect, the outer part is north of $70.0^{\circ} \mathrm{N}$, the middle part between $69.0^{\circ} \mathrm{N}$ and $70.0^{\circ} \mathrm{N}$, and the inner part between $68.4^{\circ} \mathrm{N}$ and $69.0^{\circ} \mathrm{N}$. On the Svinøy transect the outer part is north of $64.0^{\circ} \mathrm{N}$, the middle part between $63.0^{\circ} \mathrm{N}$ and $64.0^{\circ} \mathrm{N}$, and the inner part between $62.4^{\circ} \mathrm{N}$ and $63.00^{\circ} \mathrm{N}$. 


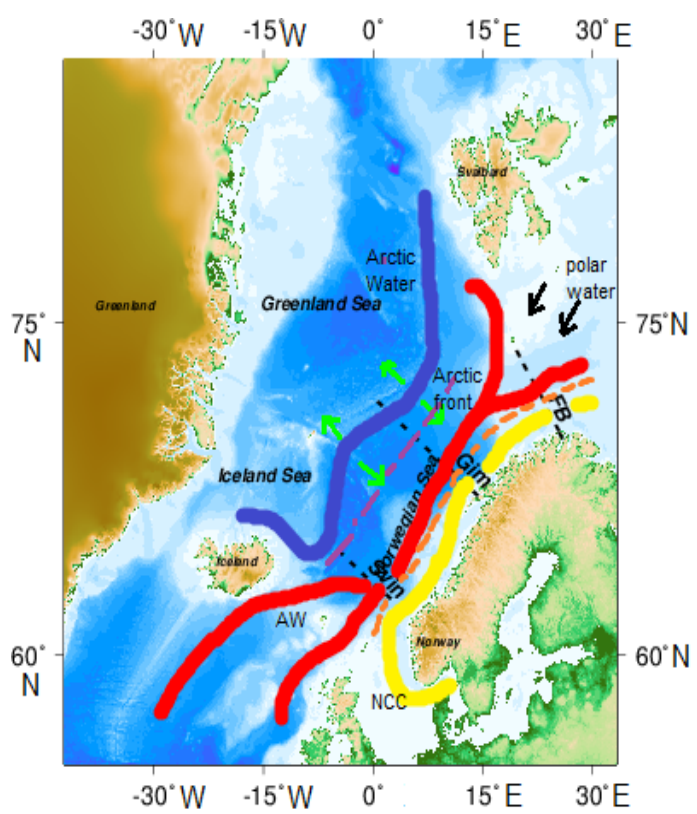

Fig. 4. Map of the Nordic seas illustrating the Norwegian Sea with three transects, the yellow line shows the Norwegian Coastal Current, the orange line shows the Atlantic Water, the dashed red line shows the front between these, and the dashed black line shows the front between the Atlantic Water and the Arctic Water (Arc W).

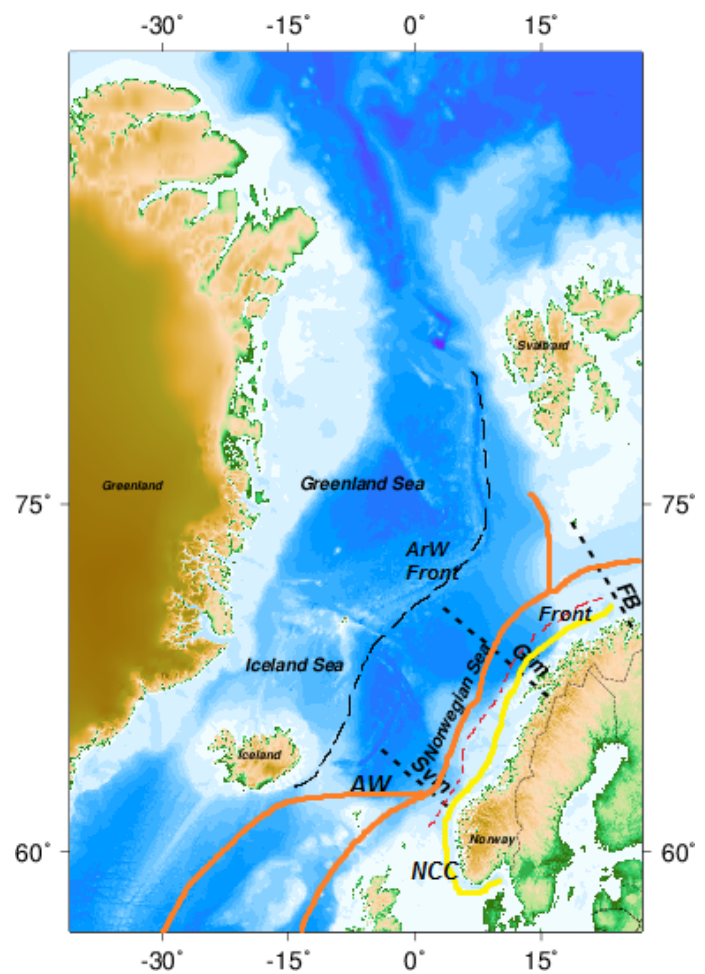

Fig. 5. The Norwegian Sea including transects, Fugløya-Bjørnøya in the North, Gims $\varnothing y$ in the Middle, Svinøy in the south of Norway respectively. Each transect split into three boxes named from onshore to offshore, inner part, middle part, and outer part.

TABLE I: LIMITS OF PARTS DEGREES NORTH

\begin{tabular}{|c|c|c|c|}
\hline Name of transect & Outer Part & Middle Part & Inner Part \\
\hline Fugløya-Bjørnøya & $73-74.26$ & $72.0-73.0$ & $70.5-72$ \\
\hline Gimsøy & $70-70.41$ & $69.0-70.0$ & $68.4-69$ \\
\hline Svin $\varnothing \mathrm{y}$ & $64-64.70$ & $63.0-64.0$ & $62.4-63$ \\
\hline
\end{tabular}

Fig. 6 illustrates the spatial and temporal distribution of the data. The distribution of the stations is different from one transect to another, and every transect is divided to three parts as shown with horizontal red lines at Fugløya-Bjørnøya, horizontal orange lines at Gimsøy, and horizontal green lines at Svinøy. In the Fugløya-Bjørnøya transect the number of hydrographic measurements in the outer part is large compared with the outer in the Gimsøy and Svinøy.
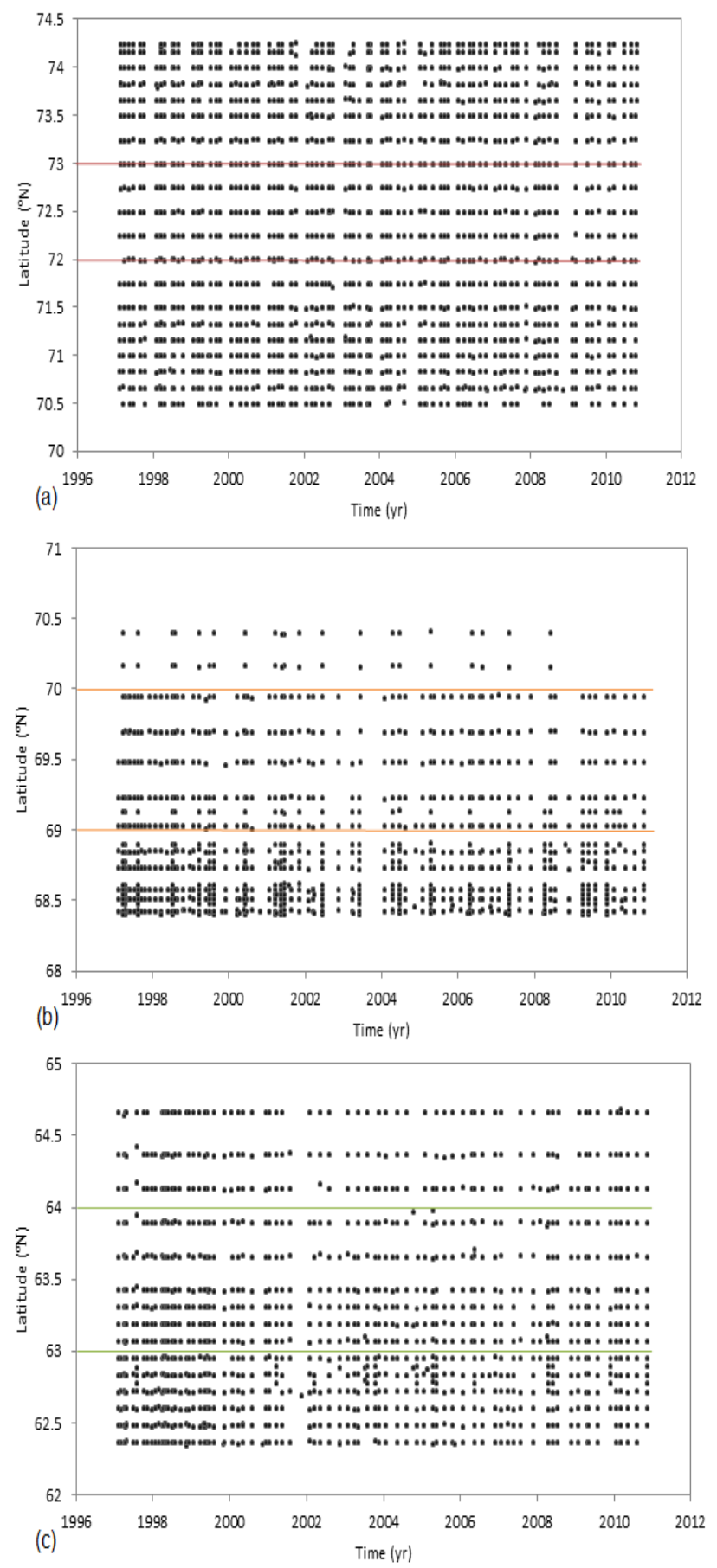

Fig. 6. Temporal and spatial distribution of the stations, (a) Fugløya-Bjørnøya (b) Gimsøy and (c) Svinøy.

\section{RESUlts AND Discussion}

\section{A. Fuglфya-Bjфrnфya Transect}

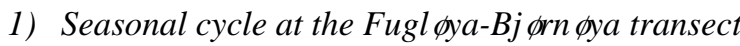

a) Outer part

Definition of the phytoplankton bloom is a "high concentration of phytoplankton in an area, caused by increased reproduction; [this] often produces discoloration of the water" [29]. The seasonal development of temperature, salinity and nitrate at the outer part of Fugløya-Bjørnøya 
transect located between $70.5^{\circ} \mathrm{N}$ and $71.0^{\circ} \mathrm{N}$ is shown in (Fig. 7) where the average of hydrographic data have been taken from the outer stations for different cruises for all years have been combined on a single time axis. The data have been collected, covering for most part the time periods from the bloom until the post bloom phase. Where the bloom defined as a time of the nitrate has started to decrease in the early of spring. And the post-bloom defined as the time period following the bloom period when the nitrate is almost depleted during summer. The temperature and nutrient concentration show a clear and high repeated seasonal cycle, (see Fig. 7). Up until day 100 low temperature indicate that winter situation prevails, with salinity quite stable at values normally above 34.7 indicating the presence of polar water and high nitrate concentrations $\left(>9.6 \_\mathrm{mol} / \mathrm{kg}\right)$.
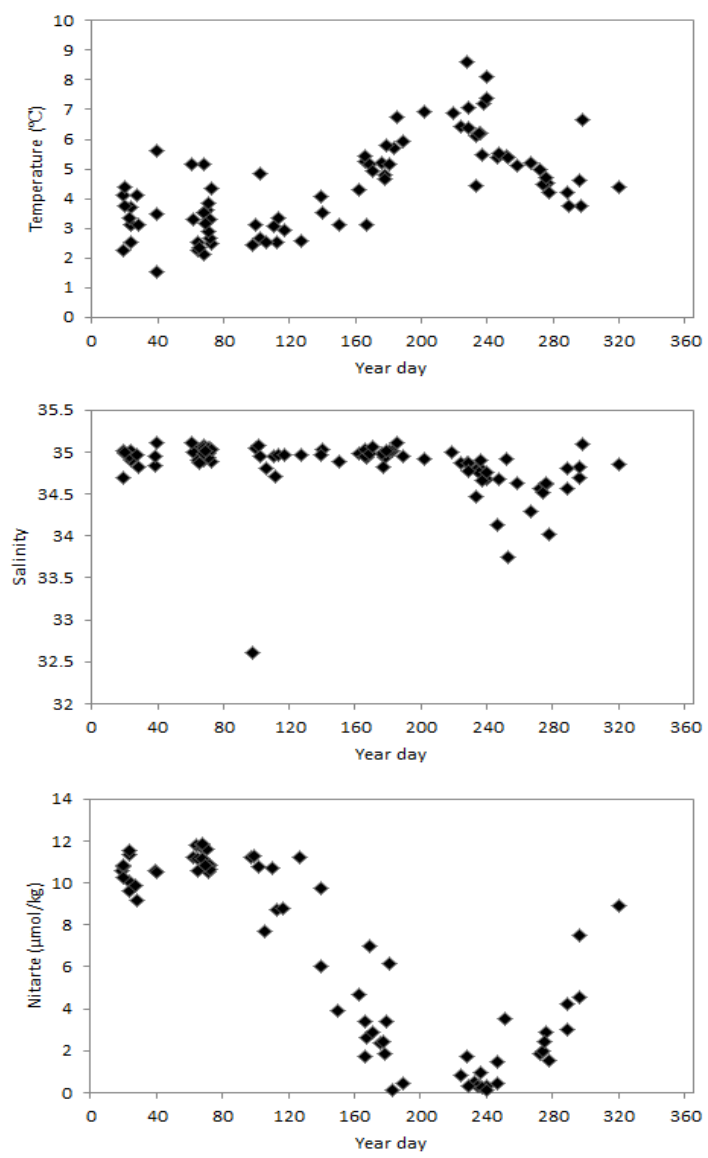

Fig. 7. The average temperature, salinity and concentration of nitrate in the upper $10 \mathrm{~m}$ in the outer part of the Fugløya-Bjørnøya transect versus the year day.

In the period between days 100 and 200, (see Table II), the sea surface temperatures increases from $3^{\circ} \mathrm{C}$ to $7^{\circ} \mathrm{C}$, while the waters become depleted in nitrate. During the bloom period the temperature increases, with the almost stable salinity, it indicates that the bloom caused mainly by heating. It is evidence to be the same result obtained from [30]. The lowest concentration of nitrate is found during period between days 200 and 250 (see Table II), this is the post-bloom period, because most of the nutrients, including nitrate, have been consumed by phytoplankton during the bloom period. After day 250 , we move to the fall situation, which will finally tend to the winter situation. The average value of salinity in the outer part during the bloom period is about 35 indicate that this water mass of Atlantic Water. Despite of during the post-bloom period appears two water masses; Atlantic Water and Polar Water are dominant in this period. In one year we observe salinity as low as 32.6. This is may be due to Polar Water.

TABLE II: BLOOM AND POST-BLOOM PERIODS AT THE THREE PARTS OF FUGLØYA BJøRNØYA TRANSECT

\begin{tabular}{lll}
\hline Parts & Bloom & Post-bloom \\
\hline Outer & $100-200$ & $200-250$ \\
Middle & $127-200$ & $200-250$ \\
Inner & $140-200$ & $200-250$ \\
\hline
\end{tabular}

\section{b) Middle part}

The seasonal cycles of average temperature, salinity, and concentration of nitrate in the middle part of Fugløya-Bjørnøya transect are shown in (Fig. 8) where the average of data from the middle stations for different cruises for all years have been combined on a single time axis. The temperature and nutrient concentrations in the middle part of Fugløya-Bjørnøya show obvious and higher repeated seasonal cycle. Up till day 127 , the winter situation prevails and the water column homogenous while salinity average around 35.0. In this part of the Fugløya- Bjørnøya transect days 127 appears to demark the start of the spring bloom (see Table II), and until day 200 the surface waters warm from $2.6^{\circ} \mathrm{C}$ to $7.0^{\circ} \mathrm{C}$, while concentrations of nitrate drop from 10.0 to $4.7 \mu \mathrm{mol} / \mathrm{kg}$. And through the bloom period there appears to be an overall slight decline in salinity and quite low values, down to 34.6 have been encountered in the post- bloom phase, which we define as occurring between day 200 and 250 (see Table II). The salinity average in the middle part is about 34.9 referred to Atlantic Water.

\section{c) Inner part}

The seasonal cycle of average temperature, salinity, and concentration of nitrate in the inner part of Fugløya-Bjørnøya transect are shown in (Fig. 9) where the average of data from the inner stations for different cruises for all years have been combined on a single time axis. The temperature and nitrate show a clear seasonal cycle as depicted in (Fig. 9). Up until year day 140 the winter situation prevails, also we can see high values of salinity around 34.5 and nitrate around 10 $\mu \mathrm{mol} / \mathrm{kg}$. Days 140 to 200 demark the spring bloom, and the temperature increases, with quite stable in the salinity while nitrate increases (see Table II). The period between days 200 to 250 is recognized as post-bloom period, with nitrate from 0.02 to $0.5 \mu \mathrm{mol} / \mathrm{kg}$. We can see appreciably high temperatures compare to the bloom period in the three parts. Also we can observe considerably low concentration of nitrate in the post-bloom period is caused by phytoplankton productivity. The salinity in the post-bloom period is relatively low. This is perhaps due the high amounts of Coastal Water. Shortly after days 250, the fall situation prevails, in this period we can see noticeable decreases in temperature and increasing of nitrate concentration. We can summarize sequences of seasonality of three parts in Fugløya Bjørnøya transect, the bloom started in the outer part earlier than in middle part, and in the middle part earlier than in inner part with a little bit different in the mean values of temperature, salinity, and nitrate. The post-bloom sets in all parts are almost at same time period. From the salinity average about 34.5 (see Fig. 9), we can infer that water mass 
is referred to Norwegian Coastal Water. Finally, in the outer part the bloom is supported by increasing up of temperature. Also the bloom in the middle part is supported by increasing of temperature and also is affected by decreasing of salinity due to amounts of coastal water. The bloom in the inner part is supported by increasing of the temperature.
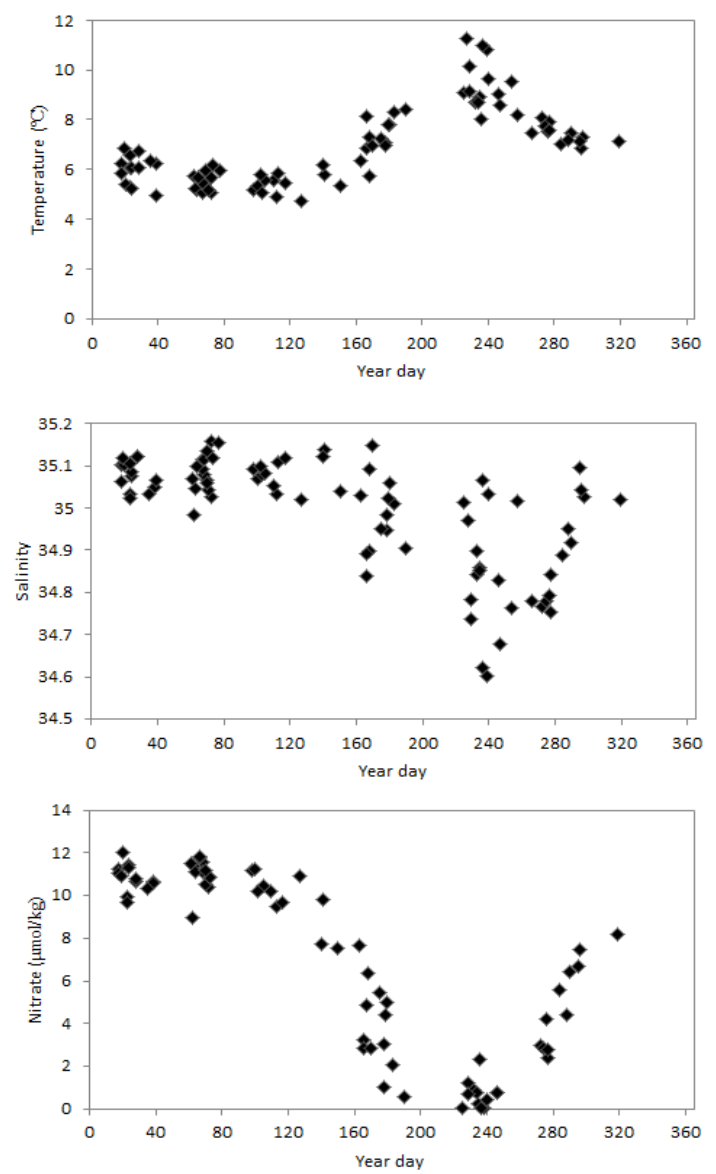

Fig. 8. The average temperature, salinity and concentration of nitrate in the upper $10 \mathrm{~m}$ in the middle part of the Fugløya-Bjørnøya transect versus the year day.

\section{B. Gimsфy Transect}

\section{1) Seasonal cycle at the Gimsфy transect}

\section{a) Outer part}

The seasonal development of temperature, salinity and nitrate at the outer part of the Gimsøy transect shown in (Fig. 10). Only few data have been collected, (see Fig. 6b), covering for the most part the time periods until the post bloom phase. This is because the Gims $\varnothing$ y transect is normally cut short at $70.41^{\circ} \mathrm{N}$, whereas we start this part at $68.4^{\circ} \mathrm{N}$. Until day 120 a winter situation prevails, with salinity quite stable at values normally above 35.1 are high, indicating the presence of Atlantic Water. Nitrate concentrations 10 $\mu \mathrm{mol} / \mathrm{kg}$. Over the time period from day 120 to 185 , (see Table III) the surface temperatures increase by almost 6 degrees, from $6{ }^{\circ} \mathrm{C}$ to $12{ }^{\circ} \mathrm{C}$, while the waters become depleted in nitrate. From the few data that exits in this region, the post-bloom period appears to be limited to within days 185 and 250, (see Table III). The surface waters are depleted of nitrate in this time period, and in some years, lower salinities are observed, indicating the presence of lower salinity Arctic Water. The bloom has induced by the heating over the outer part. The average value of salinity of 35.0 indicate that this water mass is Atlantic Water.
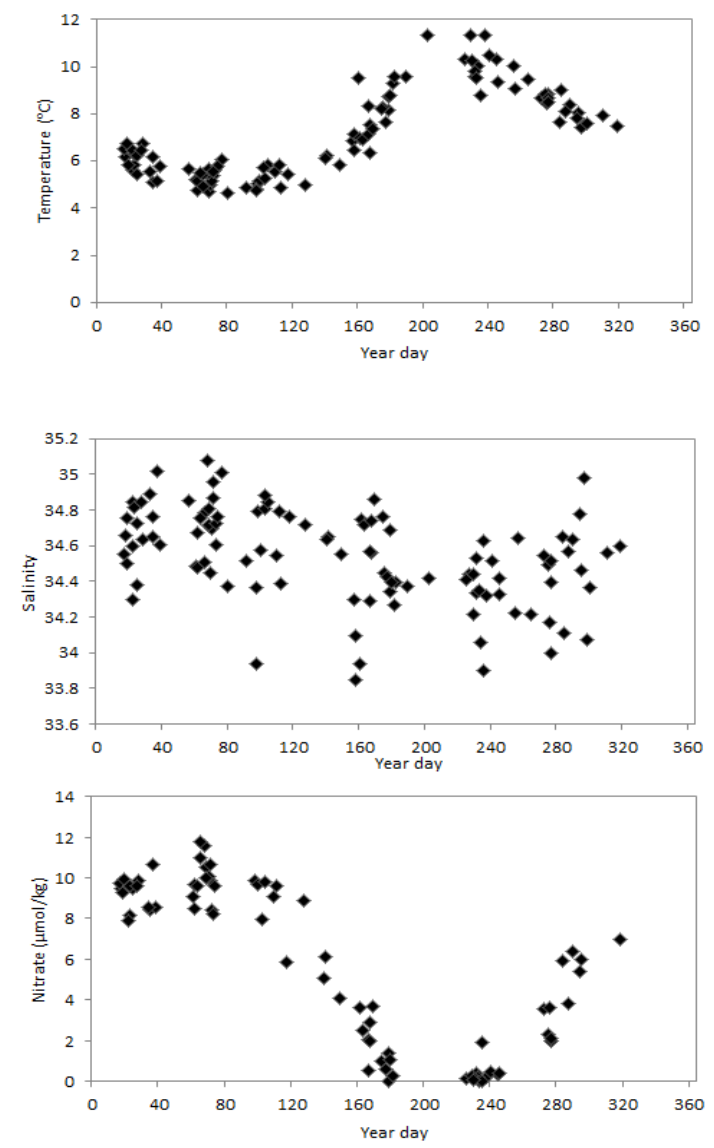

Fig. 9. The average temperature, salinity and concentration of nitrate in the upper $10 \mathrm{~m}$ in the inner part of the Fugløya-Bjørnøya transect versus the year day.
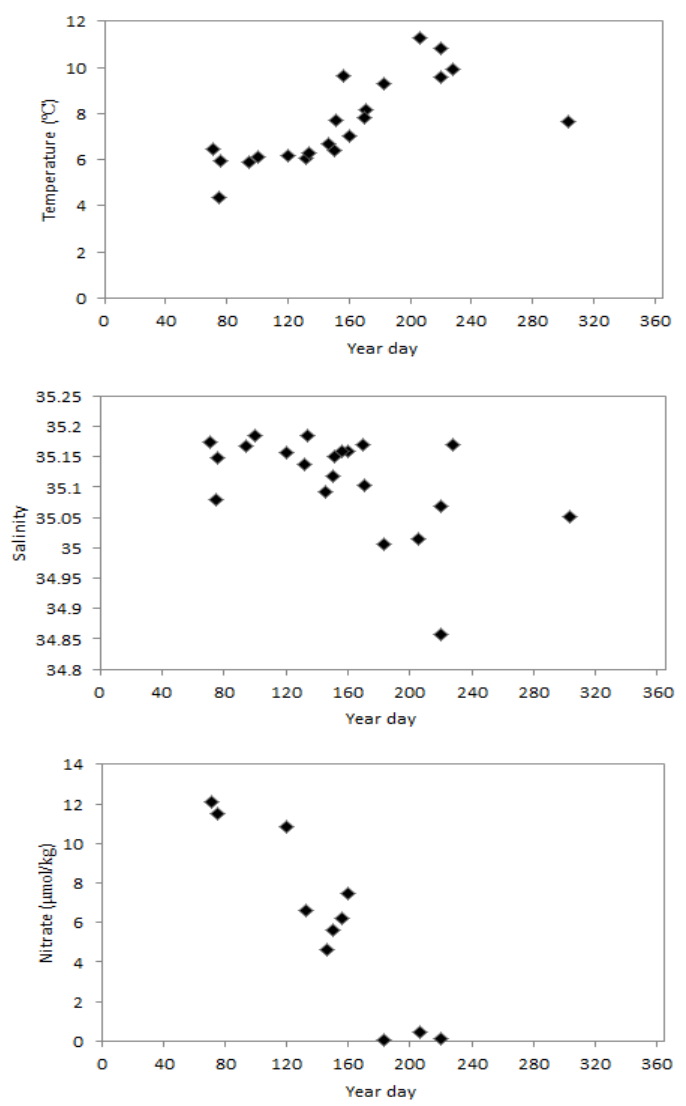

Fig. 10. The average temperature, salinity and concentration of nitrate in the upper $10 \mathrm{~m}$ in the outer part of the Gimsøy transect versus the year day. 
TABLE III: BLOOM AND POST-BloOM PERIODS AT THE THREE PARTS OF

\begin{tabular}{lll} 
& GIMSøY TRANSECT \\
\hline Parts & Bloom & Post-bloom \\
\hline Outer & $120-185$ & $185-250$ \\
Middle & $120-180$ & $180-250$ \\
Inner & $120-190$ & $190-250$ \\
\hline
\end{tabular}

From the few data that exits in this region, the post-bloom period appears to be limited to within days 185 and 250 , (see Table III). The surface waters are depleted of nitrate in this time period, and in some years, lower salinities are observed, indicating the presence of lower salinity Arctic Water. The bloom has induced by the heating over the outer part. The average value of salinity of 35.0 indicate that this water mass is Atlantic Water.
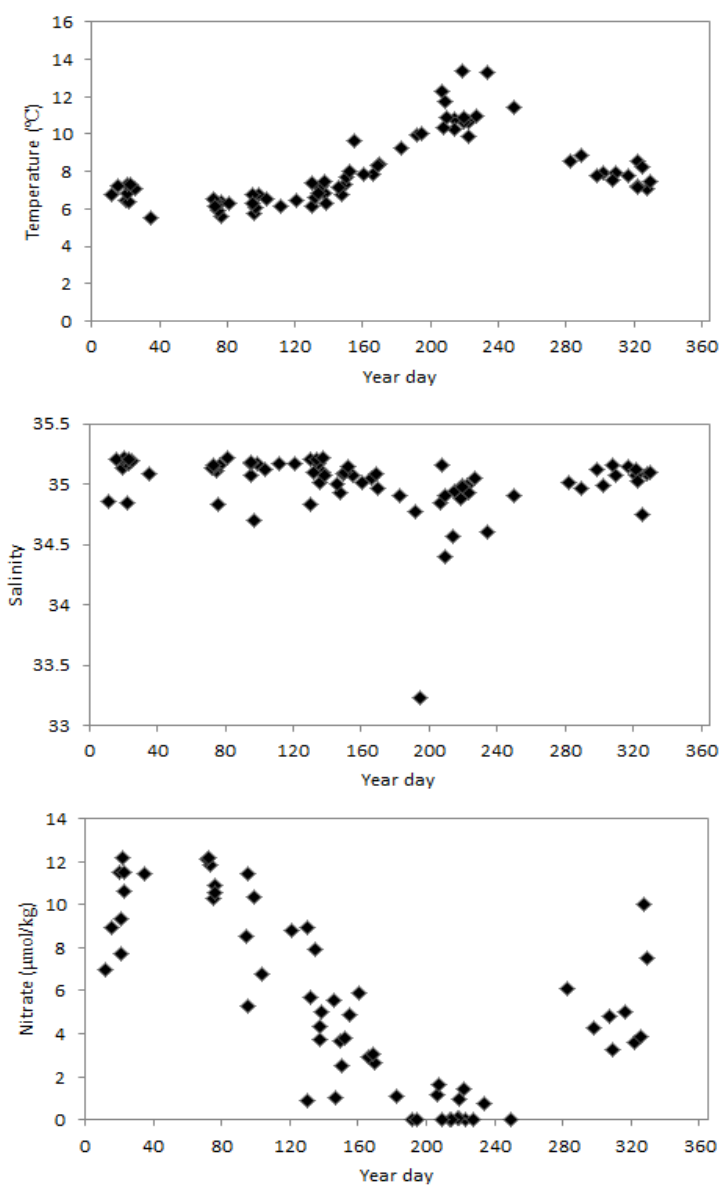

Fig. 11. The average temperature, salinity and concentration of nitrate in the upper $10 \mathrm{~m}$ in the middle part of the Gimsøy transect versus the year day.

\section{b) Middle part}

The seasonal development of average temperature, salinity and concentration of nitrate in the middle part of Gims $\varnothing y$ transect are shown in (see Fig. 11). Also in this part of the Gimsøy transect, day 120 appears to demark the start of the spring bloom, and until day 180 , (see Table III) the surface waters warms from about $6.4{ }^{\circ} \mathrm{C}$ to $9.3{ }^{\circ} \mathrm{C}$, while concentrations of nitrate drops from about $8.8 \mu \mathrm{mol} / \mathrm{kg}$ to 1.1 $\mu \mathrm{mol} / \mathrm{kg}$. In one year salinity drops below 35 in winter, maybe due to the coastal water and through the bloom period there appears to be an overall slight decline in salinity and quite low values, down to 34.5 have been encountered in the post bloom period, which we define as occurring between day 180 and 250, (see Table III). In one year we observe salinity as low as 33.2. This is maybe due to the coastal water.
Nutrients are not typically depleted in the post-bloom phase, nitrate concentrations seem to lie between 0 and almost 2 $\mu \mathrm{mol} / \mathrm{kg}$ (see Fig. 11), and there is no any consequence between the salinity and temperature versus the nitrate during the post-bloom period. These explain that bloom has caused by heating also in this part. The average salinity value about 34.9 is referred as the Atlantic Water but in some years is below 34.7 might be due to the coastal water.
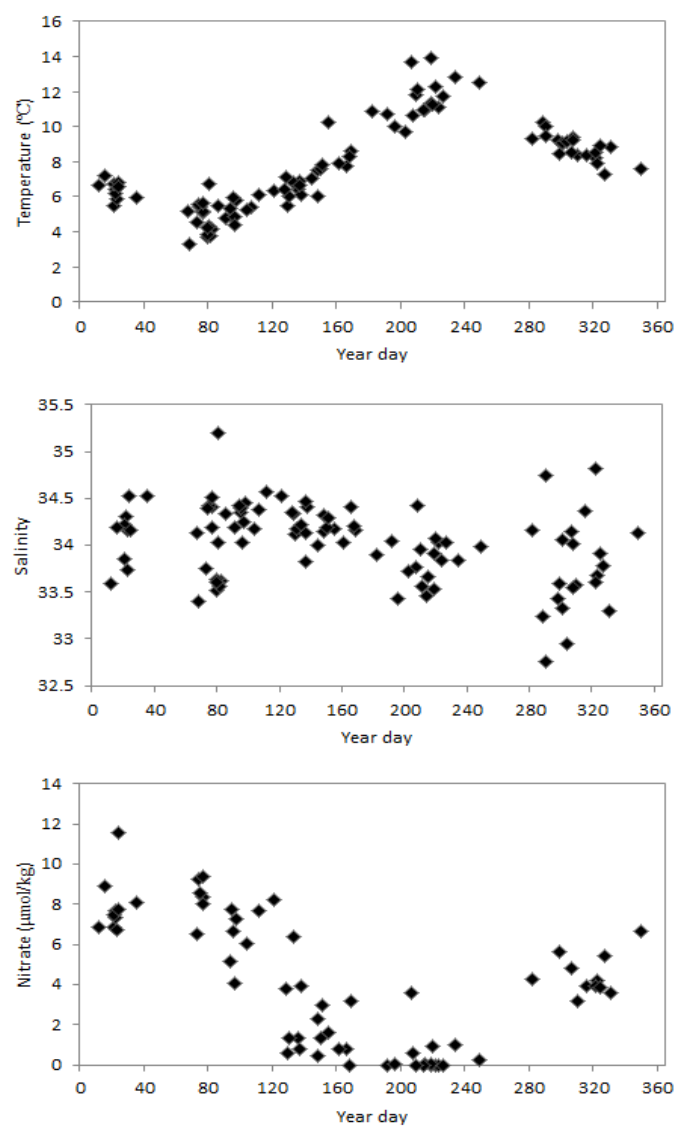

Fig. 12. The average of temperature, salinity and concentration of nitrate in the upper $10 \mathrm{~m}$ in the inner part of the Gims $\varnothing \mathrm{y}$ transect versus the year day.

\section{c) Inner part}

The seasonal development of average temperature, salinity and concentration of nitrate in the inner part of Gimsøy transect are shown in (Fig. 12), where the average of hydrographic data have been taken from the inner stations for different cruises for all years and been combined on a single time axis. The temperature and nitrate show a clear seasonal cycle, illustrated in (Fig. 12). Up until day 120 the winter state prevails with low temperature and high nutrients concentration. This is followed the spring bloom period between days 120 and 190, (see Table III), when temperature rise and the nutrient concentrations begin to decrease. The rising temperatures and the stable salinity reveal that heating is the main mechanism causing the stratification of the water column that triggers the bloom [31].

As depicted in (Table III), between days 190 and 250, there is a post-bloom period when the nitrate concentrations are very low. After day 250, temperatures again begin to decrease and the nutrient concentrations increase, because in this time might be there is a high amount of run-off water come from fjord and at the same time nutrient comes from vertical mixing as it moves into the fall and winter situation. 
Early in the fall, the salinities are lower than during the rest of the year. This is explaining by high runoff water from fjords. From the salinity average about 34.0 , (see Fig. 12), we can infer that water mass is Norwegian Coastal Water.

\section{Svinфy Transect}

\section{1) Seasonal cycle at the Svinøy transect}

a) Outer part
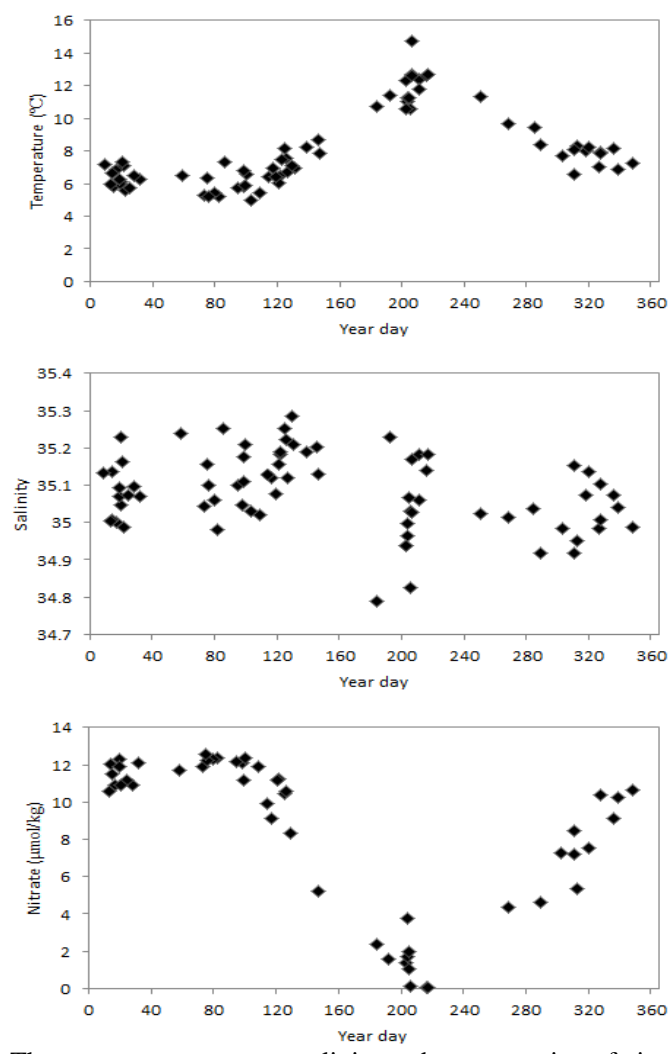

Fig. 13. The average temperature, salinity and concentration of nitrate in the upper $10 \mathrm{~m}$ at in the outer part of the Svinøy transect versus the year day.

The seasonal development of the temperature, salinity and nitrate shown in (Fig. 13) at the outer part of the Svinøy transect is located between $64.0^{\circ} \mathrm{N}$ and $64.7^{\circ} \mathrm{N}$. The nutrients and temperature show clear seasonal cycle as depicted in (Fig. 13). Up until day 100 the winter situation prevails with low temperatures around $5.8^{\circ} \mathrm{C}$ and high nitrate concentrations around $11.9 \mu \mathrm{mol} / \mathrm{kg}$ (see Fig. 13). This is followed by the spring bloom period (see Table IV) between day 100 and day 150 when temperatures rise from $5.4{ }^{\circ} \mathrm{C}$ to $7.8^{\circ} \mathrm{C}$ and the nitrate concentrations start to decrease from $11.9 \mu \mathrm{mol} / \mathrm{kg}$ to $5.2 \mu \mathrm{mol} / \mathrm{kg}$.

TABLE IV: Bloom AND Post-Bloom Periods at Three Parts of

\begin{tabular}{lll}
\multicolumn{3}{c}{ SVINøY TRANSECT } \\
\hline Parts & Bloom & Post-bloom \\
\hline Outer & $100-200$ & $200-250$ \\
Middle & $120-150$ & $150-220$ \\
Inner & $90-150$ & $150-220$ \\
\hline
\end{tabular}

The rising temperatures and the stable salinity suggest that heating is the main mechanism causing the stratification of the water column that triggers the bloom [31]. After day 216, the nitrate concentration was zero. After day 250, the temperatures again begin to decrease and the nutrient concentrations increase as we move into the fall and winter state. The salinity average value of seasonal cycle is about 35.1 dominated by Atlantic Water.

b) Middle part
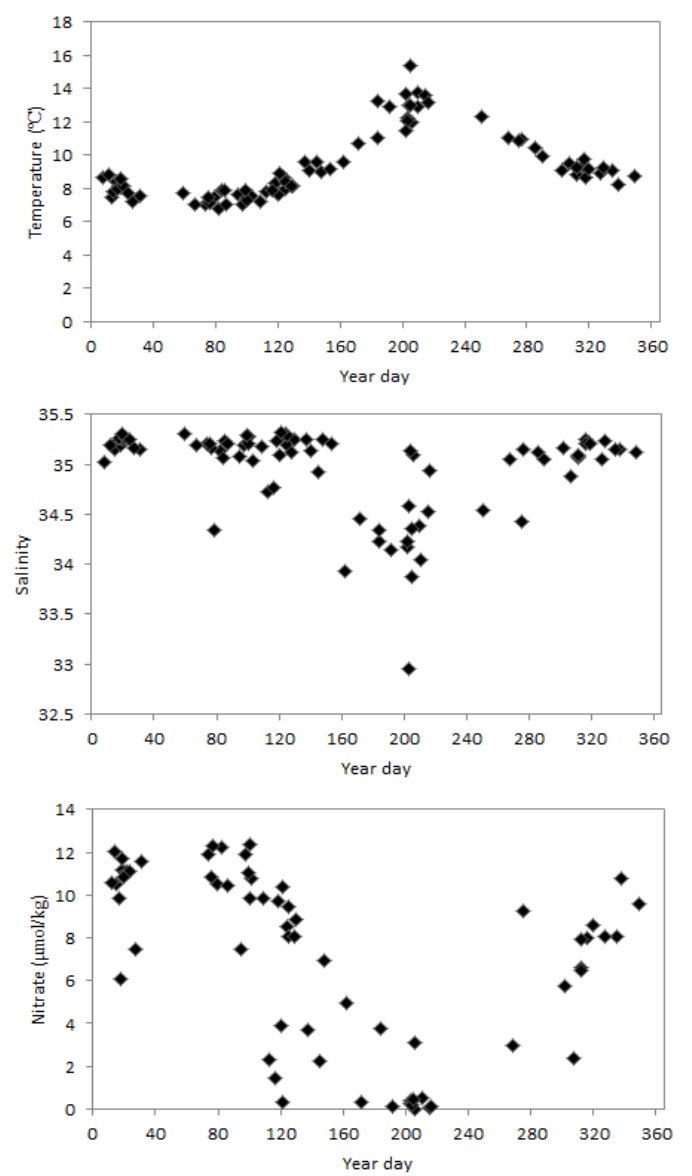

Fig. 14. The average temperature, salinity and concentration of nitrate in the upper $10 \mathrm{~m}$ in the middle part of the Svinøy transect versus the year day.

The seasonal cycle development of average temperature, salinity and concentration of nitrate in the middle part of Svinøy transect are shown in (Fig. 14). The temperature and nutrients show a clear seasonal cycle (see Fig. 14). Up till day 100 the winter state prevails with low temperature around $6.8^{\circ} \mathrm{C}$ and nutrient concentrations around $11.5 \mu \mathrm{mol} / \mathrm{kg}$. This followed the spring bloom period between days 100 to 150 when temperature rise from $7.2{ }^{\circ} \mathrm{C}$ to $15.0^{\circ} \mathrm{C}$ and nutrient concentration begin to decrease from $9.9 \mu \mathrm{mol} / \mathrm{kg}$ to 2.2 $\mu \mathrm{mol} / \mathrm{kg}$.

The rising of temperature and slow dropping of salinity suggest that the heating are main mechanism caused the stratification of water column that triggers the bloom. Between days 150 to 220 (see Table IV); there is a post-bloom when the nutrient concentrations are near zero. There is a clear dropping of salinity during the post-bloom period. This indicates there is water masses advection from the coastal water with average salinity about 34 . After day 220 the temperatures again begin to decrease from $13.6^{\circ} \mathrm{C}$ to $8.2{ }^{\circ} \mathrm{C}$ and the nutrient concentrations increase from 2.6 $\mu \mathrm{mol} / \mathrm{kg}$ to $10.8 \mu \mathrm{mol} / \mathrm{kg}$. The salinity average over the middle part as depicted in (Fig. 14) appears that two water masses found are the Atlantic Water and Coastal Water.

\section{c) Inner part}

The seasonal cycle of average temperature, salinity and concentration of nitrate in the inner part of Svinøy transect 
are shown in (Fig. 15), where the average of data has taken from the inner stations. The temperature and nutrient concentrations show a clear seasonal cycle (see Fig. 15). Up until day 90 the winter situation has prevailed with low temperatures and high nutrient concentrations. This is followed the spring bloom period between days 90 to 150 (see Table IV) when temperature rise and nutrient concentrations begin to decrease. The rising temperatures and the stable salinity suggest that the heating is the main mechanism caused the stratification of the water column that triggers the bloom [31]. Between days 150 to 220 there is a post-bloom period when the nutrient concentrations are near to zero. After day 220 the temperatures again begin to decrease and the nutrient concentrations increase as we move into the fall and winter state. Early in the fall the salinities are lower than during the rest of the year. The salinity average value of the seasonal cycle is about 33.5 clearly marking this as Norwegian Coastal Water.
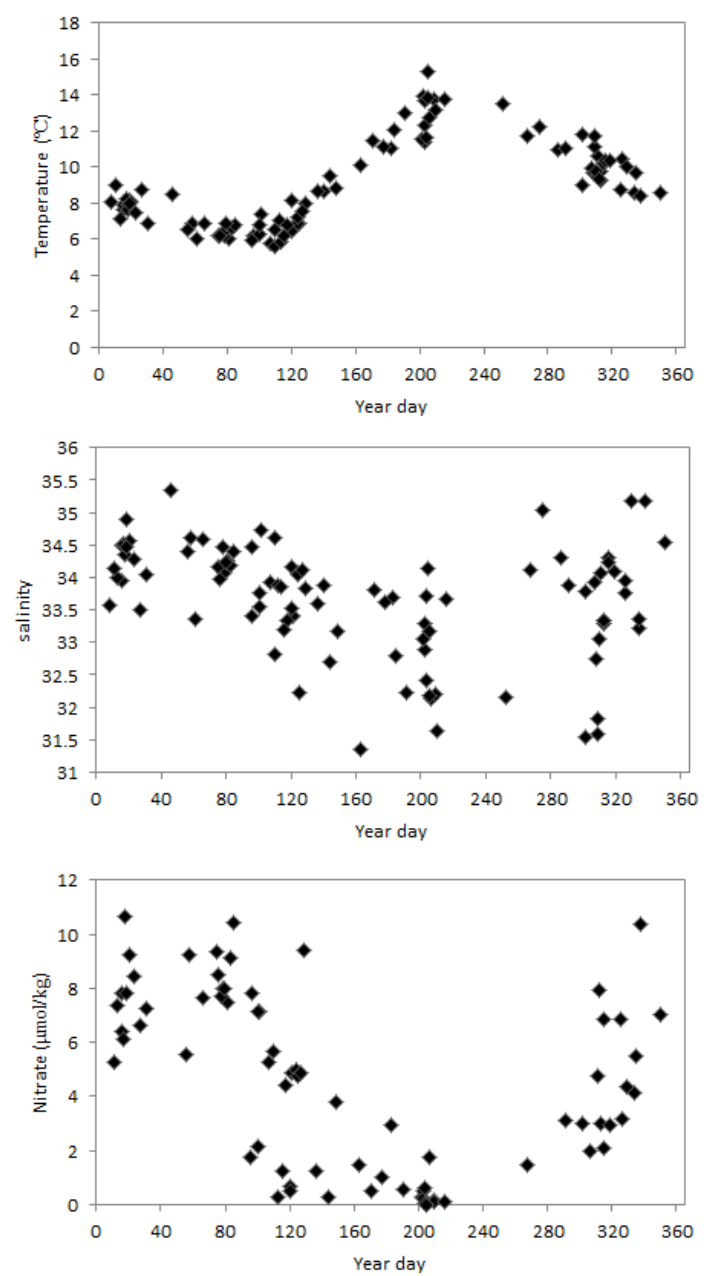

Fig. 15. The average temperature, salinity and concentration of nitrate in the upper $10 \mathrm{~m}$ in the inner part of the Svinøy transect versus the year day.

\section{COMPARISON OF THE THREE TRANSECTS}

The bloom over the Svinøy transect started before the bloom in the Gims $\varnothing y$ transect. While the bloom in the Gimsøy transect started before the Fugløya-Bjørnøya transect. This is because the cooling increases northward. And this is corresponded with changes of the temperature over the three transects during the bloom period. Along the Fugløya-Bjørnøya transect the bloom begins first in the outer part early and from there to the middle part to the inner part as depicted in (Table V). The early beginning of the bloom in the outer part is due to the shallow mixed layer formed by the Polar Water. This is confirmed by the low temperature value over the outer part during the bloom period. In winter the high value of the sea surface temperature observes at the Svinøy transect and from there decreases to the Gimsøy transect to the Fugløya-Bjørnøya transect as illustrated in (Table V). The nitrate over the three transects show low nitrate concentration in the inner part compared with the outer and middle parts during the winter. This is because the inner part is dominated by the coastal water while the middle and outer parts are dominated by Atlantic Water. The temperature, salinity, and nitrate over all transects show reasonably good seasonal cycle as showed in (Table V). The mean value of the nitrate depletion over the Svinøy transect is higher than the Fugløya-Bjørnøya transect, and the Gimsøy transect during the post-bloom period (see Table V). The data revealed weakness in the spatial and temporal covering of the three transects, because reflect of the clear seasonal cycle of the nutrients and temperature depend on the timing of the cruise when was carried out.

TABLE V: REPRESENTS THE AVERAGE OF TEMPERATURE, SALINITY, AND NitRATE DURING THE WinTER, BLOOM, AND POST-BlOOM PERIODS OVER THE Three Transects, in AdDition START AND END OF BloOM. SB Is START OF BLOOM, EB IS THE END OF BLOOM, SF IS THE START OF FALL, WSST IS THE WINTER SEA SURface TEMPERATURE, WN IS THE WINTER Nitrate, BSST Is THE BloOM SEA SURFACE TEMPERATURE, BSSS IS THE BloOm SEA Surface SALINITy, AND PB IS THE POST-BloOM

\begin{tabular}{lllllllllllll} 
B Transect & Part & SB & EB & SF & WSST & WSSS & WN & BSST & BSSS & PBSST & PBSSS & PBN \\
\hline \multirow{4}{*}{ Fugloya } & Outer & 100 & 200 & 250 & $3.3 \pm 0.9$ & $34.90 \pm 0.4$ & $10.9 \pm 0.7$ & $4.9 \pm 1.3$ & $34.96 \pm 0.09$ & $6.5 \pm 1.1$ & $34.71 \pm 0.2$ & $0.6 \pm 0.5$ \\
& Middle & 127 & 200 & 250 & $5.7 \pm 0.5$ & $35.08 \pm 0.03$ & $10.8 \pm 0.6$ & $6.9 \pm 1.5$ & $35.00 \pm 0.1$ & $9.4 \pm 1.0$ & $34.80 \pm 0.1$ & $0.7 \pm 0.6$ \\
& Inner & 140 & 200 & 250 & $5.5 \pm 0.5$ & $34.6 \pm 0.2$ & $9.4 \pm 1.1$ & $7.7 \pm 1.2$ & $34.46 \pm 0.3$ & $10.5 \pm 1.1$ & $34.40 \pm 0.2$ & $0.4 \pm 0.5$ \\
& Outer & 120 & 185 & 250 & $5.8 \pm 0.8$ & $35.16 \pm 0.04$ & $11.5 \pm 0.6$ & $7.4 \pm 1.3$ & $35.1 \pm 0.05$ & $10.4 \pm 0.8$ & $35.03 \pm 0.1$ & $0.3 \pm 0.3$ \\
Gimsøy & Middle & 120 & 180 & 250 & $6.5 \pm 0.5$ & $35.09 \pm 0.1$ & $10.0 \pm 2.0$ & $7.4 \pm 0.8$ & $35.08 \pm 0.1$ & $11.1 \pm 1.1$ & $34.76 \pm 0.4$ & $0.4 \pm 0.6$ \\
& Inner & 120 & 190 & 250 & $5.4 \pm 1.0$ & $34.08 \pm 0.4$ & $7.6 \pm 1.5$ & $7.3 \pm 1.3$ & $34.21 \pm 0.2$ & $11.6 \pm 1.2$ & $33.84 \pm 0.3$ & $0.4 \pm 0.9$ \\
& Outer & 100 & 200 & 240 & $6.2 \pm 0.6$ & $35.09 \pm 0.08$ & $11.8 \pm 0.6$ & $8.1 \pm 1.6$ & $35.09 \pm 0.1$ & $12.1 \pm 1.1$ & $35.04 \pm 0.1$ & $1.3 \pm 1.3$ \\
Svingy & Middle & 100 & 150 & 240 & $7.7 \pm 0.5$ & $35.17 \pm 0.2$ & $10.7 \pm 1.6$ & $8.2 \pm 0.7$ & $35.16 \pm 0.2$ & $12.4 \pm 1.6$ & $34.36 \pm 0.5$ & $0.8 \pm 1.6$ \\
& Inner & 90 & 150 & 240 & $7.3 \pm 0.9$ & $34.27 \pm 0.4$ & $7.9 \pm 1.4$ & $7.1 \pm 1.1$ & $33.68 \pm 0.6$ & $12.6 \pm 1.3$ & $32.89 \pm 0.8$ & $0.6 \pm 0.8$ \\
\hline
\end{tabular}

\section{CONCLUSION}

The results over the three transects indicate that the data covering and the time of the cruise have significant effect on the seasonal and interannual variation, and there is not much information on the interannual variations. The Fugløya-Bjørnøya transect showed good signature of the seasonal cycle over the three parts during the bloom and post-bloom periods. The operational definition of the bloom and post-bloom done in this work depends on when nitrate drop down during the bloom period until almost depleted during the post-bloom. The bloom evolution of the outer, middle, and inner parts of the Fugløya- Bjørnøya transect are triggered by the heating mainly. Also at the outer part the evolution is affected by the shallow mixed layer created by the Polar Water corresponded with the values of temperature and salinity in (Table V). The Gims $\varnothing y$ transect showed good seasonal cycle over the middle and inner parts during the bloom and post-bloom periods, but the outer part did not show seasonal cycle during the two periods. The evolution of the bloom at the outer, middle, and inner parts of the Gimsøy transect is caused mainly by the heating. The Svinøy transect showed good seasonal cycle over the three parts during the bloom and post-bloom periods. The bloom evolution over the three parts of the Svinøy transect is triggered by the heating. 
The bloom was started from the south to the north as illustrated in (Table V). This is because the cooling increases northward [8], [32].

\section{REFERENCES}

[1] H. Paerl, L. Valdes, J. Pinckney, M. Piehler, J. Dyble, and P. Moisander, "Phytoplankton photopigments as indicators of estuarine and coastal eutrophication," BioScience, vol. 53, no. 10, pp. 953-964, 2003.

[2] G. Hays, A. Richardson, and C. Robinson, "Climate change and marine plankton," Trends in Ecology \& Evolution, vol. 20, no. 6, pp. 337-344, 2005.

[3] K. Mann and J. Lazier, Dynamics of Marine Ecosystems: BiologicalPhysical Interactions in the Oceans, Wiley-Blackwell, 2006.

[4] W. Broecker, "The great ocean conveyor," Oceanography, vol. 4, no. 2, pp. 79-89, 1991.

[5] P. Clark, N. Pisias, T. Stocker, A. Weaver et al., "The role of the thermohaline circulation in abrupt climate change," Nature, vol. 415 , no. 6874, pp. 863-869, 2002.

[6] D. Dorritie, "Killer in our midst-methane catastrophes in Earth's past and near future," 2004

[7] NESTA. (2012). National earth science teachers association. thermohaline circulation: The global ocean conveyor. [Online] Available: http://www. windows2universe.org/earth/Water/circulation1.html

[8] J. Blindheim and S. Osterhus, "The Nordic Seas, main oceanographic features," Geophysical Monograph-American Geophysical Union, vol. 158 , p. 11, 2005.

[9] Marine Odyssey. (2012). An introduction to the marine realm, primary productivity. [Online]. Available: http://marineodyssey.co.uk/ primaryproductivity.html

[10] G. McKinley, A. Fay, T. Takahashi, and N. Metzl, "Convergence of atmospheric and North Atlantic carbon dioxide trends on multidecadal timescales," Nature Geoscience, vol. 4, no. 9, pp. 606-610, 2011.

[11] M. Vinogradov, "Ecosystems of equatorial up wellings," in Analysis of Marine Ecosystems, A. Longhurst, Ed., N.Y.: Academic Press, 1981, pp. 69-93.

[12] A. Longhurst, S. Sathyendranath, T. Platt, and C. Caverhill, "An estimate of global primary production in the ocean from satellite radiometer data," Journal of Plankton Research, vol. 17, no. 6, 1995.

[13] M. Fossheim, E. Nilssen, and M. Aschan, "Fish assemblages in the Barents Sea," Marine Biology Research, vol. 2, no. 4, pp. 260-269, 2006.

[14] H. Loeng and K. Drinkwater, "An overview of the ecosystems of the Barents and Norwegian Seas and their response to climate variability," Deep Sea Research Part II: Topical Studies in Oceanography, vol. 54, no. 23- 26, pp. 2478-2500, 2007.

[15] Sea WiFS Project. (2012). NASA/Goddard space flight center and orbimage. biosphere \& climate change. [Online] Available: http://www.plantsciences.ucdavis.edu/plantsciences_

Faculty/Bloom/CAMEL/biosphere.html

[16] F. Rey, "Phytoplankton: The grass of the sea," The Norwegian Sea Ecosystem, pp. 97-136, 2004.

[17] W. Melle, B. Ellertsen, and H. Skjoldal, "Zooplankton: the link to higher trophic levels," The Norwegian Sea Ecosystem, pp. 137-202, 2004.

[18] B. Nieho, H. Hirche, and U. Båmstedt, "The reproduction of Calanus finmarchicus in the Norwegian Sea in spring," Sarsia, vol. 85, no. 1, pp. 15-22, 2000.

[19] J. Sarmiento and N. Gruber, Ocean Biogeochemical Dynamics, Cambridge Univ Press, vol. 503, 2006.

[20] M. Skogen, W. Budgell, and F. Rey, "Interannual variability in Nordic seas primary production," ICES Journal of Marine Science: Journal du Conseil, vol. 64, no. 5, pp. 889-898, 2007.

[21] J. Ryther, "Photosynthesis in the ocean as a function of light intensity," Limnology and Oceanography, pp. 61-70, 1956.

[22] J. Johannessen and H. Gade, "A case study of the variations in the upper ocean at ocean weather shop mike $(660 \mathrm{~N}, 20 \mathrm{E})$ in the Norwegian Sea," Geofysiske Publikasjoner, vol. 32, no. 5, pp. 165-175, 1984.

[23] H. Skjoldal, T. Noji, J. Giske, J. Fosså, J. Blindheim, and S. Sundby, "Mare cognitum. Science plan for research on marine ecology of the Nordic Seas (Greenland, Norwegian, Iceland Seas) 1993-2000," A Regional GLOBEC Program with Contributions also to WOCE and JGOFS, vol. 162, Institute of Marine Research, Bergen, Norway, 1993.
[24] T. Dale, F. Rey, and B. Heimdal, "Seasonal development of phytoplankton at a high latitude oceanic site," Sarsia: A Norwegian Journal of Marine Biology, vol. 84, 1999.

[25] A. Olsen, "Three studies of interannual variations in ocean biogeochemistry at Northern High Latitudes," PhD thesis, University of Bergen, June 2002.

[26] A. Folkard, "Automatic analysis of water nutrients," Tech. Rep. 46, Fisheries Research, 1978.

[27] K. Grassho, K. Kremling, and M. Ehrhardt, "Methods of seawater analysis. Third, completely revised and extended edition," Wiley-VCH, Weinheim, vol. 77, no. 89, pp. 160, 1999.

[28] D. Hydes, M. Aoyama, A. Aminot et al., "Determination of dissolved nutrients $(\mathrm{N}, \mathrm{P}, \mathrm{Si})$ in seawater with high precision and inter-comparability using gas-segmented continuous flow analysers," The GO-SHIP Repeat Hydrography Manual: A Collection of Expert Reports and Guidelines, IOCCP Report No 14, ICPO, UNESCO/IOC, no. 134 , version 1 , pp. 1-87, 2010.

[29] T. Garrison, Oceanography: An Invitation to Marine Science, Belmont CA, 2005.

[30] A. Olsen, T. Johannessen, and F. Rey, "On the nature of the factors that control spring bloom development at the entrance to the Barents Sea and their interannual variability," Sarsia, vol. 88, no. 6, pp. 379-393, 2003.

[31] H. Sverdrup, "On conditions for the vernal blooming of phytoplankton," Journal du Conseil, vol. 18, no. 3, pp. 287-295, 1953.

[32] B. Hansen and S. Østerhus, "North Atlantic-nordic seas exchanges," Progress in Oceanography, vol. 45, no. 2, pp. 109-208, 2000.



Ahmed Ibrahim was born in Sudan on January 30, 1986 He graduated from the Chemistry Department (Honor first class), Sudan University of Science and Technology (SUST), Sudan 2008. He received M.Sc degree in chemical oceanography from University of Bergen, Norway 2012. He is working in the Higher Council of Environment and Development, Sudan. His research interests include phytoplankton primary production and the nutrients in the Nordic Seas. And the trace heavy metals speciation, and its bioavailability in the Red Sea. Now he is a PhD student at marine chemistry department, King Abdulaziz University.

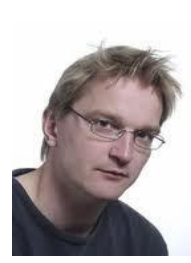

Are Olsen was born in Norway. He did his Cand. Mag., Science in University of Bergen 1994. He received M.Sc degree in synthetic organic chemistry from University of Bergen, Norway in 1997. He received his Ph.D. from the University of Bergen in Chemical Oceanography in 2002. He was a coordinator of Global Ocean Data Analysis version 2 (GLODAPv2), 2011. He was a scientific steering group member of the International ocean carbon coordination project of UNESCO -IOC \& SCOR, 2010. One of his interests is processes governing air - sea $\mathrm{CO} 2$ transfer. $\mathrm{He}$ is with Bjerknes Center for Climate Research, University of Bergen, Norway.

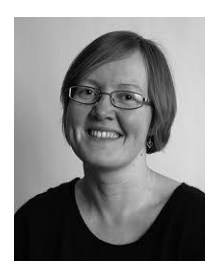

Siv Lauvset was born in Norway. She is a Ph.D. scientist in chemical oceanography with special focus on the inorganic carbon cycle in the ocean. She interests in oceanic uptake of $\mathrm{CO}_{2}$, including variations and changes. The study area is the North Atlantic and the Nordic Sea. She is with Bjerknes Center for Climate Research, university of Bergen, Norway.

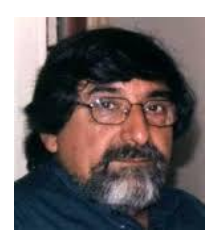

Francisco Rey was born Chile, October 4, 1945. He graduated from the Institute of Oceanology University of Chile, marine Biology, 1969. He received NORAD fellowship in Marin Biology and Chemical Oceanography, September 1971 to August 1972, from Institute of Marine Research, University of Oslo. He is with Institute of Marine Research, Oslo. He interests in phytoplankton ecology of Norwegian waters. 